\title{
Penanaman Karakter Gemar Membaca Melalui Kegiatan Literasi Sekolah pada Siswa Kelas III Sekolah Dasar
}

\author{
Yuli Yulianti ${ }^{1 *}$, Encep Andriana ${ }^{2}$ Suparno $^{3}$ \\ 1,2,3 Jurusan Pendidikan Guru Sekolah Dasar, Universitas Sultan Ageng Tirtayasa, \\ Banten, Indonesia \\ *Email: yuliy2397@gmail.com
}

\begin{abstract}
Masalah Pendidikan mengenai kurangnya gemar membaca sangat memprihatinkan. Sampai saat ini belum bisa membaca, keadaan ini membawa pengaruh yang buruk terhadap kemajuan dan kesejahteraan bangsa. Tujuan penelitian ini adalah menganalisis penanaman karakter gemar membaca pada siswa melalui kegiatan literasi sekolah. Teknik pengumpulan data menggunakan observasi, wawancara, dan dokumentasi. Teknik analisis data yang digunakan yaitu teknik analisis data statistik deskriptif kualitatif.. Hasil penelitian menunjukkan bahwa guru sudah baik dalam menanamkan karakter gemar membaca pada siswa melalui kegiatan literasi sekolah, semua itu dapat dilihat dari cara siswa mengikuti pembelajaran di kelas dan juga pernyataan yang Ibu Aat lontarkan kepada peneliti. Dalam penanamannya, pada kegiatan membaca di kelas berpengaruh/berdampak baik terhadap siswa. Berdasarkan pengamatan, siswa mampu membiasakan kegiatan membaca baik di sekolah maupun diluar sekolah setelah diterapkannya kegiatan literasi di kelas yang dilakukan setiap hari Implikasi penelitian ini yaitu dapat memberikan pemahaman mengenai penanaman nilai karakter gemar membaca, sehingga dapat memberikan kontribusi dalam pencapaian prestasi siswa dan sekolah.
\end{abstract}

Kata Kunci: Character Planting, Likes Reading, Literacy

\begin{abstract}
The problem of education regarding the lack of fondness for reading are very concerning. Until now, they have not been able to read, this situation has a bad influence on the progress and welfare of the nation. The purpose of this study was to analyze the inculcation of the character of reading fondness in students through school literacy activities. Data collection techniques using observation, interviews, and documentation. The data analysis technique used is descriptive qualitative statistical data analysis technique. The results show that teachers are good at instilling a reading habit in students through school literacy activities, all of which can be seen from the way students take part in learning in class and also the statement that Mrs. Aat pass it on to the researcher. In its cultivation, reading activities in class have a good impact on students. Based on observations, students are able to get used to reading activities both at school and outside of school after the implementation of literacy activities in the classroom which are carried out every day.
\end{abstract}

Keywords: Penanaman Karakter, Gemar Membaca, Literasi

\section{PENDAHULUAN}

Pendidikan merupakan komponen penting dalam kehidupan. Pendidikan berperan untuk menyiapkan sumber daya manusia yang kompeten, dalam mewujudkan hal tersebut diperlukan langkah utama seperti membimbing peserta didik untuk menyiapkan generasi penerus sehingga dapat mengembangkan potensi sumber daya manusia yang ada secara optimal (Dwijayani, 2019; Puspawati, 2019). Kemajuan suatu bangsa ditentukan dari karakter sumber daya manusianya, setiap bangsa maju memiliki kualitas sumber daya manusia yang berkarakter (Hidayah, 2015; Yulianti et al., 2014). Tentunya, karakter yang menjadi tolak ukur dari kemajuan suatu bangsa tersebut adalah karakter baik seperti jujur, tekun, gotong royong, disiplin, pekerja keras, mandiri, ulet, tanggungjawab, dan lain sebagainya (Khusniati, 2014; Ramdhani et al., 2019). Pendidikan

${ }^{*}$ Corresponding author.

Received December 2020; Accepted March 04 2021; Available online April 25, 2021

(C) 2020 IVCEJ. All Rights Reserved

Indonesian Values and Character Education Journal (IVCEJ) | 7 
karakter anak menjadi perhatian utama bagi para praktisi dan akademisi di Indonesia. Hal ini disebabkan karena pendidikan karakter anak dijadikan sebagai upaya untuk mempersiapkan kualitas sumber daya manusia yang handal (Inanna, 2013; Onde et al., 2020). Karakter yang baik tidak diperoleh secara instan tentu melalui proses yang panjang, sebab itu pendidikan karakter hendaknya dilakukan sedini mungkin pada usia anak-anak. Diharapkan ketika anak tumbuh dewasa maka karakter anak tersebut akan semakin kuat dan tidak mudah digoyahkan. Pendidikan karakter seyogyanya berangkat dari keluarga terlebih dahulu (Purandina et al., 2020; Rosikum, 2018).

Masalah pendidikan yang ada di Indonesia yaitu dari tenaga pendidik yang kurang berkualitas, dampaknya akan menjalar keseluruh lapisan masyarakat khususnya peserta didik yang pertama kali mendapatkan pengajaran dan didikan dari pendidik. Selain pendidik masalah lainnya yang dihadapi dunia pendidikan di Indonesia yaitu rendahnya prestasi siswa (Safitri \& Yuniwati, 2019; Wulandari, 2019). Hal ini dapat disebabkan oleh beberapa faktor, diantaranya yaitu dapat berupa faktor internal maupun faktor eksternal. Hal ini semakin terbukti dengan pemaparan yang dijabarkan langsung oleh UNESCO bahwa indeks prestasi manusia yang ada pada Indonesia semakin menurun. Menurut hasil survei UNESCO pada tahun 2016, minat membaca orang Indonesia sangat rendah. Bahkan dari enam puluh satu negara yang di survei, Indonesia menempati urutan ke enam puluh dengan tingkat minat 0,001\%. Pemaparan tersebut merupakan salah satu bencana intelektual yang dilupakan oleh pemerintah, sebab andai bencana ini tidak ditanggulangi dengan serius, Indonesia kelak hanya akan menjadi bangsa yang tertinggal, karena membaca merupakan salah satu senjata untuk mengarungi masa modern. Tidak peduli sebanyak apapun sumber daya alam yang kita miliki, jika kualitas sumber daya manusianya sangat rendah, maka ketertinggalan itu akan menjadi nyata khususnya dalam hal gemar membaca. Hal tersebut sangat jelas perbandingannya dengan negara lain (Sumaryanti, 2020; Susilo \& Khabibah, 2010).

Dibandingkan dengan negara lain di dunia, budaya membaca di Indonesia jelas masih tertinggal. Bahkan dari nama Indonesia tidak masuk dalam 10 besar negara yang selama ini lebih maju dalam soal melek huruf. Beberapa lembaga menempatkan tingkat literasi Indonesia sangat tertinggal jauh dengan banyak negara, bahkan di tingkat Asia Tenggara. Berdasarkan penelitian Programme for Internasional Student Assessment (PISA) 2019, skor membaca Indonesia ada di peringkat 72 dari 77 negara untuk kategori membaca. Rendahnya membaca ini tak lepas dari masih tingginya angka buta huruf di Indonesia. Berdasarkan Pusat Data dan Statistik Kemendikbud 2015, angka buta huruf Indonesia mencapai 5.984.075 orang. Angka buta huruf ini tersebar di 6 provinsi meliputi, Jawa Barat (604.683 Orang), Jawa Tengah (943.683 Orang), Jawa Timur (1.258.184 Orang), Nusa Tenggara Barat (315.258 Orang), Sulawesi Selatan (375. 221 Orang), dan Papua (584.441 Orang). Berdasarkan uraian diatas pendidikan mempunyai tujuan yang akan dicapai, namun permasalahannya yaitu kurangnya motivasi dari masing-masing individu sendiri untuk mencapai tujuan tersebut, terlebih lagi masyarakat Indonesia sudah terbiasa dengan sikap acuhnya terhadap permasalahan pendidikan. Perlunya peningkatan sumber daya manusia, karena sumber daya manusia sangat mendukung terhadap kemajuan pendidikan di Indonesia. Pendidikan merupakan hal yang sangat penting bagi semua orang pada era ini. Berbicara tentang pendidikan di Indonesia, tidak akan lepas dengan masalah kurangnya gemar membaca baik pada peserta didik di bangku sekolah maupun pada lapisan masyarakat lainnya (Purwo, 2019; Ramandanu, 2019).

Berdasarkan hasil observasi dan wawancara di beberapa Sekolah Dasar yang berada di Serang, peneliti menemukan permasalahan yang sama yaitu rendahnya gemar membaca siswa. Gemar membaca siswa jika dilihat dari persentase setiap sekolah hanya 50\% - 60\% itu pun sudah dianggap bagus di tingkat Sekolah Dasar, untuk $70 \%$ ke atas belum bisa tercapai karena di Serang secara umum untuk gemar membaca masih sangat kurang, dengan demikian pentingnya membaca khususnya untuk siswa SD. Bayangkan jika siswa SD saja tidak bisa membaca atau membiasakan membaca, bagaimana mereka akan melanjutkan ke tahap yang lebih tinggi, bahkan bagaimana nasib orang-orang yang tidak mampu bersekolah, jika yang bersekolah saja tidak bisa membaca. Siswa SD merupakan usia yang cocok untuk menanamkan gemar membaca, maka tanamkan pada mereka kegemarannya terhadap membaca hingga persentase gemar membaca terus meningkat. Pencapaian persentase di SDN Banjarsari 3 khususnya di kelas III mencapai $57 \%$ dari 39 siswa. Hal ini disebabkan antara lain karena tidak ada penugasan guru untuk memotivasi anak membaca, kondisi perpustakaan tidak layak, ketersediaan buku terbatas dan buku yang tersedia tidak menarik siswa untuk membaca, sarana dan prasarana yang tersedia tidak mendukung, untuk itu sekolah mengadakan kegiatan literasi yang mewajibkan siswa untuk membaca selama 15 menit sebelum pembelajaran di mulai. Berdasarkan hasil 
penelusuran dari beberapa sekolah ternyata terdapat sekolah yang sudah mengadakan kegiatan literasi tersebut yakni SDN Banjarsari 3 Kota Serang.

Pendidikan karakter dilakukan melalui proses pembiasaan di setiap institusi pendidikan, salah satunya dengan pembiasaan membaca (Priasti \& Suyatno, 2021; Rohman, 2017). Melalui membaca kita dapat memperoleh banyak hal seperti, wawasan, ilmu pengetahuan, perkembangan dunia, perkembangan ilmu dalam lingkup dunia(Nurdiyanti \& Suryanto, 2010; Warsihna, 2016). Seorang anak yang sering membaca akan memiliki kosa kata lebih banyak dibandingkan dengan anak yang malas membaca. Melalui pembiasaan membaca seorang anak akan pandai dalam mengolah kata dan bahasanya, juga mampu mengaplikasikan kemampuan bahasanya dalam kehidupan sehari-hari (Aryani \& Fauziah, 2020; Maryani et al., 2017). Karakter gemar membaca adalah salah satu karakter penting untuk menunjang kemajuan bangsa Indonesia. Hal tersebut dapat dilihat bahwa sebagian besar negara maju memiliki budaya gemar membaca. Program penerapan karakter gemar membaca bertujuan agar masyarakat Indonesia dapat menjadi masyarakat yang memiliki kesenangan atau kegemaran membaca (Priasti \& Suyatno, 2021). Oleh karena itu, diperlukan suatu indikator untuk dapat mengetahui keberhasilannya. Gemar membaca di sekolah dapat dikatakan berhasil apabila memenuhi beberapa indikator. Indikator keberhasilan penerapan karakter gemar membaca bagi siswa di antaranya adalah pemanfaatan perpustakaan sebagai sumber belajar siswa

Beberapa temuan sebelumnya menyatakan penanaman karakter dapat melalui pendidikan kesenian lokal (Tanto et al., 2019). Representasi pendidikan karakter berbasis kearifan lokal melalui pembelajaran membatik (Ghufronudin, Zuber \& Demartoto, 2017). Rekonstruksi nilai karakter berbasis budaya Manggarai (Wahyu \& Edu, 2018). Selain itu pendidikan karakter dapat melalui sastra klasik (Juanda, 2019). Pendidikan karakter gemar membaca melalui program literasi di sekolah dasar (Priasti \& Suyatno, 2021). Belum adanya kajian terkait penanaman nilai karakter gemar membaca melalui kegiatan literasi. Sehingga tujuan penelitian ini untuk menganalisis penanaman karakter gemar membaca melalui kegiatan literasi sekolah pada siswa kelas III SDN Banjarsari 3 Kota Serang.

\section{METODE}

Penelitian ini menggunakan metode penelitian deskriptif kualitatif, yaitu suatu metode penelitian yang ditujukan untuk menggambarkan fenomena-fenomena yang ada. Penelitian kualititif memiliki kegunaan antara lain untuk memahami interaksi sosial dan memahami perasaan orang yang sulit untuk dimengerti (Sugiono, 2014). Penelitian kualitatif bertujuan untuk memahami fenomena pada subjek penelitian secara deskriptif, dalam konteks alamiah, dengan mengumpulkan data secara triangulasi, analisis data bersifat induktif dan memanfaatkan berbagai metode ilmiah yang ada sebagai instrument kunci karena dalam penelitian ini melalui merencanakan, melaksanakan, mengumpulkan data, menganalisis data, menarik kesimpulan, dan menyusun laporan penelitian. Penelitian ini dilaksanakan di SDN Banjarsari 3 Kota Serang. Sekolah tersebut merupakan salah satu sekolah dasar yang telah mengimplementasikan pendidikan karakter. Selain itu, sekolah tersebut sudah menerapkan kurikulum 2013. Subjek penelitian merupakan seseorang atau sumber memperoleh informasi. Dalam penelitian kualitatif, subjek penelitian disebut informan. Penelitian ini mengambil informan kunci dari kepala sekolah. Metode pengumpulan data pada penelitian ini menggunakan beberapa metode pengumpulan data, yaitu wawancara, teknik wawancara yang digunakan dalam penelitian ini adalah untuk memperoleh data dan informasi mengenai penerapan pendidikan karakter kedisiplin di SDN Banjarsari 3 Kota Serang, dan wawancara dilakukan kepada kepala sekolah.

Teknik analisis data yang digunakan yaitu teknik analisis data statistik deskriptif kualitatif. Analisis data dalam penelitian kualitatif dilakukan sejak sebelum memasuki lapangan, selama di lapangan, dan setelah selesai di lapangan. Namun dalam penelitian kualitatif, analisis data lebih difokuskan selama proses di lapangan bersamaan dengan pengumpulan data. Melakukan analisis adalah pekerjaan yang sulit, memerlukan kerja keras. Analisis memerlukan daya kreatif serta kemampuan intelektual yang tinggi. Data Reduction, mereduksi data berarti merangkum, memilih hal-hal pokok, memfokuskan pada hal-hal yang penting, dicari tema dan polanya dan membuang yang tidak perlu. Dengan demikian data yang telah direduksi memberikan gambaran yang lebih jelas dan memudahkan peneliti untuk melakukan pengumpulan data selanjutnya dan mencarinya bila diperlukan. Peneliti merangkum hasil penerapan pendidikan karakter kedisiplinan di SDN Banjarsari 3 Kota Serang. Yang kedua Data Display, dalam penelitian ini data-data yang telah terkumpul baik data hasil observasi terus terang atau tersamar dan dokumentasi kemudian diceritakan atau diuraikan menggunakan kata-kata. Yang ketiga 
conclusion drawing, dalam kegiatan ini peneliti menyimpulkan hasilnya dengan mengecek dan meninjau kembali mengenai data yang diperoleh dan dokumen-dokumen yang digunakan untuk memperkuat hasil observasi, kemudian peneliti menarik kesimpulan dalam bentuk deskripsi. Oleh karena itu, perlu dilakukan analisis data secara berulang-ulang berkaitan dengan penerapan pendidikan karakter kedisiplinan di SDN Banjarsari 3 Kota Serang.

\section{HASIL DAN PEMBAHASAN}

\section{Hasil}

Berdasarkan hasil wawancara diketahui bahwa RPP yang digunakan merupakan buatan sendiri, hal yang perlu dipersiapkan sebelum membuat RPP yaitu materi pelajaran, kurikulum, buku siswa, dan alat peraga atau media yang nantinya akan dituliskan di dalam RPP. Hal utama yang harus diketahui oleh guru dalam membuat RPP yaitu mengenai kurikulum karena untuk menentukan Standar Kompetensi dan Kompetensi Dasar sedangkan materinya bisa dari buku atau dari luar. Metode yang digunakan tergantung tujuan pembelajaran, metode yang sering dipakai yaitu ceramah ataupun simulasi. Adapun dalam masa pandemi hanya menggunakan metode ceramah dan tanya jawab saja. Media pembelajaran menggunakan media berupa gambar untuk menjelaskan beberapa materi, media dalam pembelajaran sangatlah penting karena media juga bisa menumbuhkan semangat kepada siswa untuk belajar termasuk belajar membaca menggunakan media yang tersedia. Pendekatan yang digunakan yaitu pendekatan kontekstual.

Kegiatan literasi di SDN Banjarsari 3 juga menerapkan kegiatan ekstrakulikuler yang terdiri dari beberapa kegiatan yang bisa mendukung minat dan potensi yang dimiliki siswa. Penanamkan karakter gemar membaca melalui kegiatan literasi yang pertama, yaitu dengan memberikan bahan bacaan yang menarik. Bahan bacaan yang menarik untuk dibaca siswa berupa bacaan yang berisi cerita atau dongeng sehingga siswa tidak merasa bosan ketika sedang membaca dan termotivasi untuk segera menyelesaikan bacaannya sehingga mengetahui akhir dari cerita yang dibaca. Bahan bacaan yang berisi cerita atau dongeng tersebut di dapat dari buku paket atau pun LKS, terkadang siswa membaca buku cerita yang dibawa dari rumahnya dimana siswa bisa saling bertukar membaca dengan teman yang lain sehingga tidak hanya satu buku cerita yang mereka baca melainkan lebih dari satu. Ketika siswa membaca buku cerita bergambar maka antusiasnya dalam membaca semakin tinggi dikarenakan gambar yang terdapat di dalam buku tersebut mampu mendorong ketertarikan siswa untuk membaca dan dapat menghilangkan rasa bosan ketika membaca.

Kedua, memberikan arahan kepada wali murid agar selalu memantau siswa ketika sedang ada di lingkungan rumah agar tidak terlalu banyak bermain melainkan menyibukan diri dengan membaca. Setiap ada pertemuan antara guru dan wali murid hal yang tidak pernah tertinggal yaitu pesan guru terhadap wali murid agar selalu memantau siswa ketika di rumah untuk membiasakan membaca, selain pertemuan secara langsung guru juga sering menanyakan kebiasaan anak ketika dirumah melalui WhatsApp pribadi wali murid. Ketiga, seluruh siswa diwajibkan untuk membaca sepulang sekolah dengan cara bergantian berdasarkan jadwal yang sudah dibuat. Dalam kegiatan literasi guru harus mampu menanamkan karakter gemar membaca anak, yang mana gemar membaca anak tidak akan sama antara satu sama lainnya. Selain itu juga gemar membaca anak tidak akan berkembang dan maju jika tidak ada orang yang dapat mendukung dan membantu dalam mengembangkannya. Kegiatan literasi setelah pulang sekolah rutin dilakukan setiap hari oleh seluruh siswa SDN Banjarsari 3 dengan cara bergantian setiap harinya yang disesuaikan dengan jadwal yang sudah dibuat oleh guru.

Metode yang digunakan tergantung tujuan pembelajaran, metode yang sering dipakai yaitu ceramah ataupun simulasi, namun ketika dalam masa pandemi hanya menggunakan metode ceramah dan tanya jawab saja untuk mengurangi penularan covid-19. Pada saat penelitian berlangsung, menggunakan metode pembelajaran ceramah dan tanya jawab harus disesuaikan dengan pembelajaran yang akan disampaikan. Adapun pada masa pandemic kegiatan pembelajaran dilakukan secara rolling dalam penggunaan kelas guna mencukupi penggunaan kelas secara keseluruhan dengan kelas yang memiliki rombel lebih dari satu. Guru merasa terbantu dalam menyampaikan materi dengan adanya kegiatan literasi. Adapun kegiatan penutup di dalam kelas ditutup dengan kesimpulan, evaluasi, tindak lanjut, membaca doa dan salam. Evaluasi yang diterapkan yaitu dengan memberikan soal, baik tes lisan maupun tes tulis dari pembelajaran yang dilakukan. Sistem penilaian dengan 3 ranah seperti pengetahuan, sikap dan keterampilan siswa, itu semua beliau nilai dari keseharian siswa.

Siswa kelas III SDN Banjarsari 3 Kota Serang sudah mulai terbiasa membaca sebelum pembelajaran dimulai, untuk pertama kali diadakan kegiatan membaca sebelum pembelajaran 
memang siswa terlihat tidak begitu menyukainya, namun setelah lama kelamaan siswa pun merasa terbiasa melakukan kegiatan membaca sebelum pembelajaran dimulai. Melihat kondisi tersebut dapat disimpulkan bahwa siswa kelas III SDN Banjarsari 3 Kota Serang mulai tertanam dalam dirinya karakter gemar membaca melalui kegiatan literasi sekolah. Tingkat kemampuan membaca siswa setelah diadakannya kegiatan literasi sekolah cukup meningkat. Sebelum diadakannya kegiatan literasi sekolah pencapaian persentase untuk gemar membaca kelas III cukup rendah yaitu sekitar $50 \%$, tetapi setelah diadakannya kegiatan literasi sekolah pencapaian persentase gemar membaca untuk kelas III SDN Banjarsari 3 Kota Serang sudah mulai meningkat menjadi sekitar $57 \%$ dari 39 siswa.

Berdasarkan hasil observasi dan wawancara dapat dilihat bahwa siswa antusias ketika mengikuti pembelajaran di kelas, semua itu dapat dibuktikan dengan kedatangan siswa ke dalam kelas dengan tepat waktu. Selama penelitian berlangsung melihat siswa datang tepat waktu ke dalam kelas sebelum guru datang ke kelas untuk melakukan pembelajaran seperti biasanya. Siswa yang sudah berada di dalam kelas langsung membuka buku dan membacanya sambil menunggu kedatangan guru ke dalam kelas. Selain itu dalam pembelajaran pun siswa terlihat lebih bersemangat mengikuti pembelajaran di kelas, sehingga dapat disimpulkan bahwa selama diterapkannya kegiatan literasi siswa lebih antusias ketika mengikuti pembelajaran di kelas. Siswa kelas III SDN Banjarsari 3 Kota Serang dapat mengikuti pembelajaran dengan baik, semua itu terbukti selama peneliti melakukan penelitian di kelas tersebut tidak ada siswa yang keluar dari ruang kelas sebelum pembelajaran berakhir. Semua siswa mengikuti pembelajaran dengan baik, begitu pula dengan pemaparan Ibu Aat bahwasanya selama ngajar di kelas III belum pernah ada siswa yang keluar tanpa seijin beliau, semua siswa mengikuti pembelajaran sampai tuntas.

Berdasarkan hasil penelitian, strategi guru dalam menanamkan karakter gemar membaca melalui kegiatan literasi sekolah. Kegiatan literasi yaitu kegiatan yang membantu siswa untuk terbiasa membaca sebelum belajar, selain itu juga untuk membantu siswa dalam meningkatkan kemampuannya dalam membaca. Hal utama yang harus diketahui oleh guru yaitu mengenai kurikulum karena untuk menentukan standar kompetensi dan kompetensi dasar. Adapun komponen yang harus dicantumkan berupa materi pembelajaran, metode pembelajaran, tujuan pembelajaran, media pembelajaran, pendekatan pembelajaran, langkah-langkah kegiatan pembelajaran dan penilaian. Komponen dan langkah-langkah pengembangan RPP, yaitu mencantumkan identitas, mencantumkan tujuan pembelajaran, mencantumkan materi pembelajaran, mencantumkan model/metode pembelajaran, mencantumkan langkah-langkah kegiatan pembelajaran, mencantumkan media/alat bahan/sumber belajar, dan mencantumkan penilaian (Rando, 2016; Susilowati et al., 2018).

Cara yang dilakukan dalam menanamkan karakter gemar membaca anak yang pertama, yaitu dengan memberikan bahan bacaan yang menarik. Kedua, memberikan arahan kepada wali murid agar selalu memantau siswa ketika sedang ada di lingkungan rumah agar tidak terlalu banyak bermain melainkan menyibukan diri dengan membaca. Ketiga, seluruh siswa diwajibkan untuk membaca sepulang sekolah dengan cara bergantian berdasarkan jadwal yang sudah dibuat. Membaca mencakup: pertama, membaca merupakan suatu proses. Maksudnya, adalah informasi dari teks atau pengetahuan yang dimiliki oleh pembaca mempunyai peranan utama dalam membentuk makna. Kedua, membaca adalah strategis (Asna \& Mimi, 2016; Nurdiyanti \& Suryanto, 2010). Pembaca yang efektif menggunakan berbagai strategi membaca yang sesuai dengan teks dan konteks dalam rangka mengonstruk makna ketika membaca. Ketiga, membaca interaktif. Keterlibatan pembaca dengan teks tergantung pada konteks. Orang yang senang membaca suatu teks yang bermanfaat, akan menemukan beberapa tujuan yang ingin dicapainya, teks yang dibaca seseorang harus mudah dipahami (readable) sehingga terjadi interaksi antara pembaca dan teks.

Perubahan tingkah laku yang didapatkan melalui hasil dari pengalaman atau hasil dari suatu pembelajaran. Metode yang digunakan dalam teori behaviorstik yaitu metode pembiasaan dimana seseorang itu harus diberikan stimulus untuk mengubah tingkah laku mereka oleh karena itu dengan pemberian stimulus tersebut membutuhkan pembiasaan agar hasil yang hendak dicapai semaksimal mungkin (Sumarmi \& Rostini, 2019). Adapun evaluasi yang diterapkan yaitu dengan memberikan soal, baik tes lisan maupun tes tulis, dari pembelajaran yang sudah dilakukan. Beliau juga menggunakan sistem penilaian dengan 3 ranah seperti pengetahuan, sikap dan keterampilan siswa, itu semua beliau nilai dari keseharian siswa. Semua itu beliau lakukan guna mengukur kemampuan siswa dan juga menentukan nilai yang didapatkan oleh masing-masing siswa. Evaluasi dilakukan berkenaan dengan proses kegiatan untuk menentukan nilai sesuatu (Nugroho \& Mawardi, 2021; Subagia \& Wiratma, 2016). Pendidikan karakter dinilai 
mampu memperbaiki karakter anak didik bangsa, didalam dunia pendidikan diharapkan tidak hanya membelajarkan aspek kognitif dan psikomotor saja, tetapi juga memperhatikan aspek afektif pada diri siswa (Surya, 2017; Veronika et al., 2013; Wahyuni et al., 2015).

Temuan ini diperkuat dengan temuan penelitian sebelumnya yang menyatakan penanaman karakter dapat melalui pendidikan kesenian lokal (Tanto et al., 2019). Representasi pendidikan karakter berbasis kearifan lokal melalui pembelajaran membatik (Ghufronudin, Zuber \& Demartoto, 2017). Rekonstruksi nilai karakter berbasis budaya Manggarai (Wahyu \& Edu, 2018). Selain itu pendidikan karakter dapat melalui sastra klasik (Juanda, 2019). Pendidikan karakter gemar membaca melalui program literasi di sekolah dasar (Priasti \& Suyatno, 2021). Implikasi penelitian ini yaitu dapat memberikan pemahaman mengenai penanaman nilai karakter gemar membaca, sehingga dapat memberikan kontribusi dalam pencapaian prestasi siswa dan sekolah.

\section{SIMPULAN DAN SARAN}

Berdasarkan hasil penelitian bahwa guru di SDN Banjarsari 3 telah dapat melaksanakan penanaman karakter gemar membaca melalui kegiatan literasi sekolah. Guru senantiasa mengetahui bagaimana strategi dalam penanaman karakter gemar membaca melalui kegiatan literasi sekolah dengan melalui beberapa tahapan. Dengan mengetahui cara guru dalam menanamkan karakter gemar membaca melalui kegiatan literasi maka telah memberikan dampak yang baik kepada peserta didik dalam pembelajaran di sekolah. Siswa disarankan agar dapat menerapkan pemahamannya terhadap kegiatan literasi yang telah dijelaskan guru disekolah untuk diterapkan baik dalam lingkungan sekolah, lingkungan keluarga, maupun lingkungan masyarakat.

\section{DAFTAR PUSTAKA}

Aryani, R., \& Fauziah, P. Y. (2020). Analisis Pola Asuh Orangtua dalam Upaya Menangani Kesulitan Membaca pada Anak Disleksia. Jurnal Obsesi, 5(2), 1128 - 1137. https://doi.org/10.31004/obsesi.v5i2.645.

Asna, \& Mimi. (2016). Peningkatan Hasil dan Kemampuan Membaca Intensif Siswa Kelas IV pada Pembelajaran Bahasa Indonesia dengan Model Pembelajaran Word Square di SD Negeri 27 Batang Anai. Jurnal Konseling Dan Pendidikan, 4(2), 74 - 78. https://doi.org/10.29210/166\%y.

Dwijayani, N. M. (2019). Development of circle learning media to improve student learning outcomes. Journal of Physics: Conference Series, 1321(2), 171-187. https://doi.org/10.1088/1742-6596/1321/2/022099.

Ghufronudin, Zuber, A., \& Demartoto, A. (2017). Representasi pendidikan karakter berbasis kearifan lokal melalui pembelajaran membatik. Jurnal Analisa Sosiologi, 6(2), 30-37. https://doi.org/10.20961/jas.v6i2.18020.

Hidayah, N. (2015). Penanaman Nilai-nilai Karakter Dalam Pembelajaran Bahasa Indonesia di Sekolah Dasar. Jurnal Pendidikan Dan Pembelajaran Dasar, 2(2). https://doi.org/10.24042/terampil.v2i2.1291.

Inanna. (2013). Peran Pendidikan Karakter Dalam Mengembangkan Kecerdasan Moral. Jurnal Pendidikan Karakter, Vol 1(1), 27-33. https://doi.org/10.21831/jpk.v0i1.1287.

Juanda, J. (2019). Pendidikan Karakter Anak Usia Dini melalui Sastra Klasik Fabel Versi Daring. Jurnal Obsesi: Jurnal Pendidikan Anak Usia Dini, 3(1), 39. https://doi.org/10.31004/obsesi.v3i1.126.

Khusniati, M. (2014). Model Pembelajaran Sains Berbasis Kearifan Lokal Dalam Menumbuhkan Karakter Konservasi. Indonesian Journal of Conservation, 3(1), 67-74. https://doi.org/10.15294/ijc.v3i1.3091.

Maryani, N., Ichsan, M., \& Khairunnisa. (2017). Signifikansi Metode Guide Reading Terhadap Motivasi Belajar Siswa Dalam Teori Membaca Nyaring Guide Reading Method On Students ' Learning Motivation In Reading Loudly Lesson. Didaktika Tauhidi: Jurnal Pendidikan Guru Sekolah Dasar, 4(2), 126-139. https://doi.org/10.30997/dt.v4i2.924.

Nugroho, A. S., \& Mawardi. (2021). Pengembangan Instrumen Penilaian Sikap Tanggungjawab dalam Pembelajaran Tematik di Sekolah Dasar. Jurnal Basicedu, 5(2), 808-817. https://doi.org/10.31004/basicedu.v5i2.825.

Nurdiyanti, E., \& Suryanto, E. (2010). Pembelajaran Literasi Mata Pelajaran Bahasa Indonesia pada Siswa Kelas V Sekolah Dasar. Paedagogia, 13(2), 115-128. https://jurnal.fkip.uns.ac.id/index.php/paedagogia/article/view/153/104. 
Onde, M. L. ode, Aswat, H., Fitriani, \& Sari, E. R. (2020). Integrasi Penguatan Pendidikan Karakter (PPK) ERA 4.0 Pada Pembelajaran Berbasis Tematik Integratif Di Sekolah Dasar. Jurnal Basicedu, 4(2), 268-279. https://doi.org/10.31004/basicedu.v4i2.321.

Priasti, S. N., \& Suyatno, S. (2021). Penerapan Pendidikan Karakter Gemar Membaca Melalui Program Literasi di Sekolah Dasar. Jurnal Kependidikan: Jurnal Hasil Penelitian Dan Kajian Kepustakaan Di Bidang Pendidikan, Pengajaran Dan Pembelajaran, 7(2), 395. https://doi.org/10.33394/jk.v7i2.3211.

Purandina, Y., Putu, I., \& Winaya, A. (2020). Pendidikan Karakter di Lingkungan Keluarga Selama Pembelajaran Jarak Jauh pada Masa Pandemi COVID-19. Cetta: Jurnal IImu Pendidikan, 3(2), 270-290. https://doi.org/10.37329/cetta.v3i2.454.

Purwo, S. (2019). Peran Gerakan Literasi Sekolah Dalam Pembelajaran Kreatif Produktif di Sekolah Dasar. Journal of Chemical Information and Modeling, 53(9), 1689-1699. https://journal.stkippgritrenggalek.ac.id/index.php/kid/article/view/85/48.

Puspawati, G. A. M. (2019). Nilai-Nilai Pendidikan Karakter dalam Ragam Gerak Tari Pendet. Jurnal Stilistika, 7(2), 274-291. https://doi.org/10.5281/zenodo.3900648.

Ramandanu, F. (2019). Gerakan Literasi Sekolah (GLS) Melalui Pemanfaatan Sudut Baca Kelas Sebagai Sarana Alternatif Penumbuhan Minat Baca Siswa. Jurnal Mimbar IImu, 24(1). https://doi.org/10.23887/mi.v24i1.17405.

Ramdhani, S., Yuliastri, N. A., Sari, S. D., \& Hasriah, S. (2019). Penanaman Nilai-Nilai Karakter melalui Kegiatan Storytelling dengan Menggunakan Cerita Rakyat Sasak pada Anak Usia Dini. Jurnal Obsesi: Jurnal Pendidikan Anak Usia Dini, 3(1), 153. https://doi.org/10.31004/obsesi.v3i1.108.

Rando, A. R. (2016). Pengembangan Perangkat Pembelajaran dalam Implementasi Strategi Contextual Teaching Learning untuk Meningkatkan Hasil Belajar IPS Pokok Bahasan Perkembangan Teknologi pada Siswa Kelas IV SD. Jurnal Pendidikan (Teori Dan Praktik), 1(1), 1-11. https://doi.org/10.26740/jp.v1n1.p1-12.

Rohman, S. (2017). Membangun Budaya Membaca Pada Anak Melalui Program Gerakan Literasi Sekolah. Jurnal Pendidikan Dan Pembelajaran Dasar, 4(1), 156.

Rosikum, R. (2018). Pola Pendidikan Karakter Religius pada Anak melalui Peran Keluarga. Jurnal Kependidikan, 6(2). https://doi.org/10.24090/jk.v6i2.1910.

Safitri, F., \& Yuniwati, C. (2019). Pengaruh Motivasi dan Dukungan Keluarga terhadap Prestasi Belajar Mahasiswa Tingkat II Prodi D-III Kebidanan Universitas Ubudiyah Indonesia. Journal of Healthcare Technology and Medicine, 2(2), 154-161. https://doi.org/10.33143/jhtm.v2i2.248.

Subagia, I. W., \& Wiratma, I. G. L. (2016). Profil Penilaian Hasil Belajar Siswa Berdasarkan Kurikulum 2013. JPI (Jurnal Pendidikan Indonesia), 5(1), 39-54. https://doi.org/10.23887/jpi-undiksha.v5i1.8293.

Sugiono. (2014). Metode Penelitian Pendidikan Pendekatan Kuantitatif, Kualitatif, dan R\&D. Alfabeta.

Sumarmi, S., \& Rostini, D. (2019). Manajemen Pembelajaran, Kompetensi Lulusan Implementasi Manajemen Pembelajaran Untuk Mempersiapkan Uji Kompetensi. Nusantara Education Review.

Sumaryanti, L. (2020). Menumbuhkan minat baca anak MI / SD dengan media buku bergambar seri. Journal Basic Of Education, 4(2), 173-183. https://doi.org/10.24269/ajbe.v4i2.2699.

Surya, Y. F. (2017). Penggunaan Model Pembelajaran Pendidikan Karakter Abad 21 pada Anak Usia Dini. Jurnal Obsesi: Jurnal Pendidikan Anak Usia Dini, 1(1), 52-61. https://doi.org/10.31004/obsesi.v1i1.30.

Susilo, Y., \& Khabibah, S. (2010). Peningkatan Motivasi Belajar Siswa Melalui Model Pembelajaran Kooperatif Tipe Numbered Head Together ( Nht ) Materi Ajar Perbandingan Dan Fungsi Trigonometri Pada Siswa Kelas X. MATHEdunesa, 2, 1.

Susilowati, S., Sajidan, S., \& Ramli, M. (2018). Keefektifan perangkat pembelajaran berbasis inquiry lesson untuk meningkatkan keterampilan berpikir kritis siswa. Jurnal Penelitian Dan Evaluasi Pendidikan, 22(1), 49-60. https://doi.org/10.21831/pep.v22i1.17836.

Tanto, O. D., Hapidin, H., \& Supena, A. (2019). Penanaman Karakter Anak Usia Dini dalam Kesenian Tradisional Tatah Sungging. Jurnal Obsesi : Jurnal Pendidikan Anak Usia Dini, 3(2), 337-345. https://doi.org/10.31004/obsesi.v3i2.192.

Veronika, P., Setiawan, B., \& Wardani, N. E. (2013). Implementasi Pembelajaran Bahasa Jawa Berbasis Pendidikan Karakter Religius dalam Kurikulum 2013. Al-Harakah, 19(1), 53-77. https://doi.org/10.18860/el.v19i1.3929. 
Wahyu, Y., \& Edu, A. L. (2018). Reconstruction of character values based on Manggaraian culture. SHS Web of Conferences, 42(00029). https://doi.org/10.1051/shsconf/20184 200029 .

Wahyuni, S., Isnarto, \& Wuryanto. (2015). Pengembangan Karakter Kedisiplinan Dan Kemampuan Pemecahan Masalah Melalui Model Laps-Heuristik Materi Lingkaran KelasViii. Unnes Journal of Mathematics Education, 4(2). https://doi.org/10.15294/ujme.v4i2.7594.

Warsihna, J. (2016). Meningkatkan Literasi Membaca dan Menulis dengan Teknologi Informasi dan Komunikasi. Kwangsan, 4(2), 67 - 80. https://doi.org/10.31800/jtp.kw.v4n2.p67--80.

Wulandari, E. T. (2019). Pentingnya Pengaruh Fasilitas Belajar Terhadap Prestasi Belajar Siswa The Importance of the Effect of Learning Facilities on Student Learning Achievement. VI, 20, EProsiding Seminar Nasional Biologi, 6(20), 258-261. http://103.76.50.195/semnasbio/article/view/10545.

Yulianti, D., S, R., H, S., \& Diana, D. (2014). Pengembangan Karakter Peduli Lingkungan Anak Usia Dini Melalui Buku Cerita Bermuatan Sains Berwawasan Konservasi. Jurnal Penelitian Pendidikan Unnes, 31(1), 124422. https://doi.org/10.15294/jpp.v31i1.5681. 